\title{
PENGARUH PEMBERIAN SARI BUAH BELIMBING WULUH (Averrhoa bilimbi L) TERHADAP TEKANAN DARAH SISTOLIK TIKUS SPRAGUE DAWLEY
}

\author{
Retno Safitri, Aryu Candra *) \\ Program Studi Ilmu Gizi Fakultas Kedokteran Universitas Diponegoro \\ Jl.Dr.Sutomo No.18, Semarang, Telp (024) 8453708, Email : gizifk@undip.ac.id
}

\begin{abstract}
Background: Hypertension is a major risk factor for cardiovascular disease, stroke, and kidney disorders. Diet is one of factors that affect the blood pressure. Increased fructose and fat diet are often associated with hypertension. Fructose and fat induce increasing blood pressure through oxidative stress which can cause vasoconstriction. Bilimbi fruit contains nutrients and antioxidants that can lower blood pressure effectively.

Method: This research is true experimental study with randomized control groups pre-post designed. Twenty one Sprague dawley rats were divided into 3 groups: 2 control groups and 1 treatment groups. Negative control groups were fed with standard diet, positive and treatment groups were fed a standard and 66\% fructose and $10 \%$ fat diet. Bilimbi juice with a dosage $2 \mathrm{ml} / 200 \mathrm{gBW} /$ day just given in treatment groups for 14 days. Measurement of systolic blood pressure by tail cuff method on days 1,16,30.

Result: The result of post test systolic blood pressure in all groups are decreased. The average number of decreased in systolic blood pressure in the negative and positive control are 3,76\% and 0,55\%, respectively. The highest decreased was found in the treatment group, 30,03\%. Administration of Bilimbi juice was able to decrease systolic blood pressure significantly $(P<0,05)$.

Conclusion: Bilimbi juice in dosage $2 \mathrm{ml} / 200 \mathrm{grBW} /$ day for 14 days has a number to decrease the systolic blood pressure of rats which fed by a high composition of fructose and fat.

Keywords: Bilimbi (Averrhoa bilimbi) juice, systolic blood pressure, fructose, fat.
\end{abstract}

\section{ABSTRAK}

Latar Belakang: Hipertensi merupakan faktor risiko utama terjadinya penyakit kardiovaskuler, stroke, dan gangguan ginjal. Salah satu faktor yang berpengaruh pada tekanan darah adalah asupan. Peningkatan asupan fruktosa dan lemak seringkali dikaitkan dengan kejadian hipertensi. Fruktosa dan lemak memediasi peningkatan tekanan darah melalui stress oksidatif yang dapat menyebabkan vasokontriksi. Buah belimbing wuluh mengandung zat gizi dan antioksidan yang efektif menurunkan tekanan darah.

Metode: Penelitian true experimental dengan randomized control groups pre-post design. Dua puluh satu tikus Sprague dawley dibagi menjadi 3 kelompok: 2 kelompok kontrol dan 1 kelompok perlakuan. Kontrol negatif diberi pakan standar, kontrol positif dan perlakuan diberi 66\% dan lemak 10\%. Sari buah sari buah belimbing wuluh dengan dosis $2 \mathrm{ml} / 200$ gramBB/hari hanya dibrikan pada kelompok perlakuan selama 14 hari. Pengukuran tekanan darah sistolik dengan metode tail cuff dilakukan pada hari ke 1, 16 dan 30.

Hasil: Hasil post test tekanan darah sistolik pada seluruh kelompok mengalami penurunan. Rerata penurunan tekanan darah sistolik kelompok kontrol negatif sebesar 3,76\% dan kontrol positif 0,55\%. Penurunan terbesar pada kelompok perlakuan yaitu 30,03\%. Pemberian sari buah belimbing wuluh mampu menurunkan tekanan darah sistolik secara signifikan $(p<0,05)$.

Kesimpulan: Pemberian sari buah belimbing wuluh dengan dosis $2 \mathrm{ml} / 200$ gramBB/hari selama 14 hari berpengaruh terhadap penurunan tekanan darah secara signifikan pada tikus yang diberi pakan tinggi fruktosa dan tinggi lemak. Kata kunci: Sari buah belimbing wuluh (Averrhoa bilimbi), tekanan darah sistolik, fruktosa, lemak.

\section{PENDAHULUAN}

Tekanan darah merupakan kekuatan yang dihasilkan oleh darah terhadap seluruh bagian dinding pembuluh darah. Kelainan yang sering terjadi pada tekanan darah adalah meningkatnya tekanan darah atau dikenal dengan tekanan darah tinggi (hipertensi). Hipertensi merupakan suatu keadaan dimana tekanan aliran darah pada dinding arteri tinggi dan terjadi secara konsisten. Tekanan darah tinggi merupakan faktor risiko utama terjadinya penyakit kardiovaskuler, stroke, dan gangguan ginjal. ${ }^{1}$ Seseorang dikatakan hipertensi apabila tekanan darah sistolik mencapai $140 \mathrm{mmHg}$ atau lebih dan tekanan darah diastolik mencapai 90 mmHg atau lebih. ${ }^{2}$

Hipertensi dilaporkan sebagai kontributor keempat kematian dini di negara maju dan ketujuh di negara berkembang. Pada orang dewasa, peningkatan tekanan darah sistolik sebesar 20 $\mathrm{mmHg}$ menyebabkan peningkatan $60 \%$ risiko kematian akibat penyakit kardiovaskuler. Prevalensi hipertensi meningkat dengan pesat di negara-negara berkembang dan merupakan salah satu penyebab utama kematian dan 
kecacatan. ${ }^{3,4,5}$ Pada tahun 2000 , hampir 1 miliar orang dewasa atau lebih dari seperempat dari populasi dunia menderita hipertensi dan diperkirakan akan meningkat menjadi 1,56 miliar pada tahun 2025. ${ }^{1,3,5}$ World Health Organization (WHO) tahun 2011 menunjukan bahwa kematian akibat hipertensi di Indonesia berada pada peringkat 84 dari 192 negara, paling tinggi diantara negara ASEAN. ${ }^{6}$ Prevalensi hipertensi di Indonesia berdasarkan Riset Kesehatan Dasar (RISKESDAS) tahun 2013 sebesar 25,8\%. ${ }^{7}$

Tekanan darah dipengaruhi oleh berbagai faktor, salah satunya adalah faktor asupan. Peningkatan asupan total fruktosa dan lemak seringkali dikaitkan dengan kejadian hipertensi. Fruktosa adalah gula yang terdapat dalam bahan makanan yang mudah dijumpai seperti permen, sirup dan buah. Penelitian pada manusia menunjukan bahwa asupan fruktosa 60 gram per hari dapat meningkatkan tekanan darah sistolik. Sedangkan asupan glukosa tidak menyebabkan kenaikan tekanan darah. ${ }^{8}$ Penelitian lain pada hewan coba yang diinduksi $66 \%$ fruktosa selama 15 hari mengalami kenaikan tekanan darah sistolik sebesar $81,8 \%$ dari tekanan darah awal. ${ }^{9}$ Fruktosa memediasi peningkatan tekanan darah melalui gangguan produksi nitric oxide (NO) yang dapat menyebabkan vasokontriksi. ${ }^{10}$

Diet rendah natrium dan tinggi kalium merupakan salah satu metode yang digunakan untuk menurunkan tekanan darah. Selain itu asupan antioksidan juga berpengaruh terhadap tekanan darah. ${ }^{2}$ Buah merupakan salah satu bahan makanan yang mengandung sumber kalium dan antioksidan. Salah satu buah yang dapat dimanfaatkan sebagai alternatif terapi hipertensi adalah belimbing wuluh.

Belimbing wuluh (Averrhoa bilimbi) merupakan tanaman tropis yang tumbuh disegala musim, mudah ditemukan dan banyak ditanam di Indonesia. Pohon belimbing wuluh berbunga dan berbuah sepanjang tahun. Kemampuan tanaman ini untuk menghasilkan buah sepanjang tahun tidak sebanding dengan pemanfaatannya, sehingga banyak buah segar yang terbuang sia-sia. Pemanfaatan belimbing wuluh di masyarakat adalah sebagai bumbu sayur, dan obat tradisional. Sebagai obat tradisional masyarakat menggunakan sebagai obat hipertensi, diabtetes, dan asam urat.

Buah belimbing wuluh matang bersifat asam dan tinggi kandungan serat dan mineral seperti kalsium, fosfor, zat besi, dan kalium. ${ }^{11,12}$ Kalium merupakan zat gizi yang sangat berperan dalam penurunan tekanan darah. ${ }^{1}$ Kalium berperan dalam memperbesar ukuran sel endotel dan meningkatkan produksi nitric oxide yang akan memicu reaksi dilatasi dan reaktivasi vaskuler yang akan menurunkan tekanan darah. ${ }^{13}$ Belimbing wuluh juga sumber vitamin C, antioksidan polifenol (flavonoid, tanin, asam fenolat, saponin), dan rendah lemak. Flavonoid dan tanin merupakan senyawa fenolik dan fenolat tanaman yang berfungsi sebagai antioksidan primer dan mempunyai potensi dalam menurunkan risiko hipertensi dan penyakit jantung. ${ }^{14,15}$

Belimbing wuluh merupakan tanaman yang dapat dimanfaatkan pada setiap bagian baik buah, daun, maupun batang. Buah belimbing wuluh mempunyai aktivitas antihipertensi, antihiperlidemia dan antihiperglikemia yang merupakan gejala sindrom metabolik. Penelitian secara in vivo, $1 \mathrm{~mL}$ jus buah belimbing wuluh dengan dosis 0,12 gram per 20 gram berat badan mencit Swiss Webster hiperkolesterolemiaper hari dapat mencegah kenaikan kadar kolesterol darah tetapi tidak dapat menurunkan kadar kolesterol darah yang sudah tinggi. ${ }^{16}$ Penelitian pada mencit hiperglikemia yang di induksi dengan aloksan, pemberian air perasan buah belimbing wuluh 30 mililiter per hari selama 5 hari secara signifikan dapat menurunkan kadar glukosa darah. ${ }^{17}$ Walaupun sudah digunakan untuk penurun tekanan darah sejak lama oleh masyarakat namun penelitian mengenai pengaruh belimbing wuluh terhadap tekanan darah masih jarang dilakukan.

Berdasarkan uraian diatas, peneliti ingin mengkaji pengaruh pemberian sari belimbing wuluh (Averrhoa bilimbi L) terhadap tekanan darah sistolik tikus Sprague Dawley yang diinduksi dengan pakan tinggi fruktosa dan tinggi lemak.

\section{METODE PENELITIAN}

Pelaksanaan penelitian telah mendapatkan persetujuan dari Komite Etik Penelitian Kesehatan Fakultas Kedokteran Universitas Diponegoro dengan terbitnya Ethical Clearance.

\section{Sampel Penelitian}

Sampel yang digunakan adalah tikus putih jantan (Rattus norvegicus) galur Sprague dawley. Pemilihan sampel berdasarkan kriteria jenis kelamin jantan, galur Sprague dawley, usia 2-3 bulan. Pemeliharaan hewan coba dilaksanakan di Laboratorium Pusat Studi Pangan dan Gizi Universitas Gajah Mada, Yogyakarta.

\section{Bahan}

Bahan yang digunakan selama penelitian berlangsung terdiri dari pakan standar, pakan tinggi fruktosa, pakan tinggi lemak, dan sari buah belimbing wuluh. Jenis pakan standar yang diberikan adalah standar Comfeed AD II. Sedangkan pakan tinggi lemak dengan penambahan margarin. Pakan tinggi fruktosa menggunakan $66 \%$ 
fruktosa dan $10 \%$ margarin. Uji kandungan zat gizi sari buah belimbing wuluh dilakukan di Laboratorium Pusat Studi Pangan dan Gizi Universitas Gajah Mada, Yogyakarta.

\section{Metode Penelitian}

Penelitian merupakan jenis penelitian true experimental dengan rancangan pre-post test with randomized control group design. Variabel bebas adalah pemberian sari buah belimbing wuluh dengan dosis $2 \mathrm{ml} / 200$ gramBB tikus. Variabel terikat adalah tekanan darah sistolik tikus Sprague Dawley. Sedangkan variabel terkontrolnya adalah galur, umur, jenis kelamin, pakan, kandang, dan sistem perkandangan hewan coba. Penentuan jumlah sampel minimal sesuai dengan kriteria Federer yaitu 6 ekor tikus pada setiap kelompok. Untuk mengantisipasi drop out maka jumlah sampel 7 ekor setiap kelompok. Jumlah sampel sebanyak 21 ekor yang dibagi ke dalam 3 kelompok yang dibagi secara acak.Subjek penelitian dibagi menjadi 3 kelompok sebagai berikut

$\mathrm{K}(-) \quad$ : Kelompok kontrol negatif (pakan standar) $\mathrm{K}(+) \quad$ : Kelompok kontrol positif (induksi pakan tinggi fruktosa dan tinggi lemak)

P : Kelompok perlakuan (induksi pakan tinggi fruktosa dan tinggi lemak, sari buah belimbing wuluh sebanyak 2 $\mathrm{ml} / 200$ gramBB tikus).

\section{Tahapan Penelitian}

Pemeliharaan sampel penelitian dilakukan di kandang individual.Selama masa penelitian pengukuran berat badan dilakukan 3 hari sekali.Pengukuran tekanan darah awal dilakukan diakhir masa aklimasi setelah dikelompokan.Aklimasi dilakukan selama 3 hari. Selanjutnya kelompok kontrol postif dan perlakuan diberi fruktosa $66 \%$ dan lemak $10 \%$ selama 15 hari melalui sonde. Pengukuran tekanan darah preintervensi dilakukan pada hari ke 16 kemudian kelompok perlakuan diberi sari buah belimbing wuluh selama 14 hari melalui sonde. Sedangkan untuk kelompok kontrol positif dan kontrol negatif dilanjutkan dengan pemberian pakan standar. Hari ke 30 dilakukan pengukuran tekanan darah akhir atau post intervensi. Tekanan darah yang diukur adalah tekanan darah sistolik dengan menggunakan metode tail cuff dengan alat Sphygmomanometer dibagian ekor. Pengukuran dilakukan dipagi hari.

Sari belimbing wuluh merupakan cairan yang diperoleh dari perasan buah belimbing wuluh (Averrhoa bilimbi) yang dipisahkan dari ampasnya. Spesifikasi belimbing wuluh yang digunakan adalah panjang buah $6-8 \mathrm{~cm}$, diameter $2,5-3,5 \mathrm{~cm}$, dan berat 22-25 g per buah. Proses pembuatan sari buah dimulai dengan belimbing wuluh dicuci dengan air bersih kemudian buah belimbing wuluh diparut kemudian diperas dan disaring untuk mendapatkan air perasan yang terpisah dari ampas. Pemberian sari buah belimbing wuluh sebanyak $2 \mathrm{ml}$ per 200 gr BB tikus selama 14 hari. Pemberian dengan menggunakan sonde 1 kali per hari.

\section{Analisis Data}

Uji normalitas menggunakan uji SaphiroWilk. Perbedaan tekanan darah sebelum dan sesudah perlakuan masing-masing kelompok diuji dengan uji $\mathrm{t}$ berpasangan. Tingkat kepercayaan yang digunakan adalah $95 \%$.

\section{HASIL PENELITIAN}

Data yang diolah berasal dari 21 subjek.Uji normalitas data menggunakan Saphiro-Wilk karena subjek kurang dari 50. Hasil uji normalitas menunjukan semua data pada masing-masing kelompok berdistribusi normal $(\mathrm{P}>0,05)$.

Perubahan Tekanan Darah Sistolik Sebelum Dan Sesudah Pemberian Pakan Tinggi Fruktosa Dan Tinggi Lemak

Tabel 1 menunjukan data tekanan darah sebelum dan sesudah pemberian pakan tinggi fruktosa dan tinggi lemak. Data tekanan darah diperoleh pada tahap akhir aklimasi dan pada hari ke-16 selama masa penelitian.

Tabel 1. Rata-rata tekanan darah sistolik sebelum dan sesudah pemberian pakan tinggi fruktosa dan tinggi lemak

\begin{tabular}{lcccccc}
\hline Kelompok & $\mathrm{n}$ & $\begin{array}{c}\text { Sebelum } \\
(\mathrm{mmHg} \pm \mathrm{SD})\end{array}$ & $\begin{array}{c}\text { Sesudah } \\
(\mathrm{mmHg} \pm \mathrm{SD})\end{array}$ & $\begin{array}{c}\Delta \\
(\mathrm{mmHg} \pm \mathrm{SD})\end{array}$ & $\% \Delta$ & $\mathrm{p}$ \\
\hline $\mathrm{K}(-)$ & 7 & $88 \pm 1,91$ & $87,57 \pm 0,61$ & $-0,43 \pm 2,76$ & 0,49 & $0,695^{*}$ \\
$\mathrm{~K}(+)$ & 7 & $89,14 \pm 4,34$ & $128,57 \pm 1,72$ & $39,42 \pm 35,52$ & 44,22 & $0,000^{* *}$ \\
$\mathrm{P}$ & 7 & $88,14 \pm 2,27$ & $128,43 \pm 0,43$ & $40,28 \pm 1,02$ & 45,70 & $0,000^{* *}$
\end{tabular}

*tidak berbeda bermakna $(\mathrm{P}>0,05) * *$ berbeda bermakna $(\mathrm{P}<0,05)$

Tabel diatas menunjukan bahwa kelompok kontrol negatif mengalami penurunan rerata tekanan darah sistolik yang tidak signifikan. Sedangkan kelompok kontrol positif dan perlakuan mengalami kenaikan rerata tekanan darah sistolik yang signifikan. Kenaikan terbesar terjadi pada kelompok perlakuan yaitu sebesar $45,7 \%$. Sehingga dapat disimpulkan bahwa terdapat perbedaan rerata tekanan darah sistolik sebelum dan sesudah pemberian pakan tinggi fruktosa dan tinggi lemak 
yang bermakna pada kelompok kontrol positif dan perlakuan.

Perubahan Tekanan Darah Sistolik Sebelum Dan Sesudah Pemberian Sari Buah Belimbing Wuluh
Data tekanan darah sistolik diperoleh pada hari ke-16 dan hari ke-30 selama masa penelitian. Data tekanan darah sistolik sebelum dan sesudah pemberian sari buah belimbing wuluh dapat dilihat pada Tabel 2.

Tabel 2. Rata-rata tekanan darah sistolik sebelum dan sesudah pemberian sari buah belimbing wuluh

\begin{tabular}{lcccccl}
\multicolumn{1}{c}{ Kelompok } & $\mathrm{N}$ & $\begin{array}{c}\text { Sebelum } \\
(\mathrm{mmHg} \pm \mathrm{SD})\end{array}$ & $\begin{array}{c}\text { Sesudah } \\
(\mathrm{mmHg} \pm \mathrm{SD})\end{array}$ & $\begin{array}{c}\Delta \\
(\mathrm{mmHg} \pm \mathrm{SD})\end{array}$ & $\% \Delta$ & $\mathrm{P}$ \\
\hline $\mathrm{K}(-)$ & 7 & $87,57 \pm 1,61$ & $84,29 \pm 3,49$ & $-3,29 \pm 1,15$ & 3,76 & $0,029^{* *}$ \\
$\mathrm{~K}(+)$ & 7 & $128,57 \pm 1,72$ & $127,86 \pm 2,54$ & $-0,71 \pm 1,25$ & 0,55 & $0,588^{*}$ \\
$\mathrm{P}$ & 7 & $128,43 \pm 1,13$ & $89,86 \pm 1,10$ & $-38,57 \pm 3,69$ & 30,03 & $0,000^{* *}$ \\
\hline
\end{tabular}

*tidak berbeda bermakna $(\mathrm{P}>0,05) * *$ berbeda bermakna $(\mathrm{P}<0,05)$

Tabel 2 menunjukan bahwa kelompok kontrol positif mengalami penurunan tekanan darah yang tidak signifikan.Sedangkan kelompok kontrol negatif dan perlakuan mengalami penurunan yang signifikan. Namun penurunan terbesar terjadi pada kelompok perlakuan yang diberi sari buah belimbing wuluh yaitu sebesar $30,03 \%$. Sehingga dapat disimpulkan bahwa pemberian sari buah belimbing wuluh dapat menurunkan tekanan darah secara signifikan.

\section{PEMBAHASAN}

Perubahan Tekanan Darah Sistolik Sebelum Dan Sesudah Pemberian Pakan Tinggi Fruktosa Dan Tinggi Lemak

Hasil analisis menunjukan adanya kenaikan tekanan darah sistolik yang signifikan setelah pemberian pakan tinggi fruktosa dan tinggi lemak selama 15 hari pada kelompok kontrol positif dan perlakuan. Sementara pada kelompok kontrol negatif mengalami penurunan yang tidak signifikan. Peningkatan tekanan darah sistolik pada kelompok kontrol positif dan perlakuan mencapai $>40 \%$ dari tekanan pre-itervensi. Hasil ini lebih rendah jika dibandingkan dengan penelitian terdahulu yaitu pemberian fruktosa $66 \%$ selama 15 hari dapat meningkatkan tekanan darah $81,8 \%$ dibandingkan dengan kelompok kontrol negatif. ${ }^{18}$

Fruktosa merupakan gula sederhana yang terdapat pada buah-buahan dan madu. Selain itu fruktosa juga terdapat dalam sukrosa atau gula pasir dan high fructose corn syrup (HFCS) yang digunakan sebagai pemanis tambahan. Konsumsi tinggi fruktosa dikaitkan dengan kenaikan tekanan darah. Fruktosa yang bersumber dari kristal fruktosa dan HFCS lebih berbahaya jika dibanding dengan fruktosa yang berasal dari bahan alami seperti yang terdapat dalam buah. Gula meja dan HFCS mengandung gukosa yang dapat mempercepat penyerapan fruktosa. Sedangkan pada bahan alami mengandung zat gizi tambahan dan antioksidan. ${ }^{19}$
Mekanisme fruktosa menimbulkan
terjadinya hipertensi pada tikus melalui pembentukan senyawa aldehid yang merupakan hasil dari metabolisme fruktosa. Aldehid berkaitan dengan membran protein grup sulfihidril yang dapat menimbulkan gangguan channels $\mathrm{Ca}^{+}$yang terdapat pada membran sel otot polos pembuluh darah. Gangguan channels $\mathrm{Ca}^{+}$akan meningkatkan kadar kalsium bebas dalam sitosol otot polos vaskuler. Peningkatan kalsium bebas menyebabkan hiperaktivitas vaskuler, vasokontriksi dan peningkatan resisitensi perifer sehingga terjadi kenaikan tekanan darah. ${ }^{20}$

Asam urat merupakan produk sampingan hasil metabolisme fruktosa. Asam urat yang tidak terkendali diduga menjadi faktor risiko terjadinya kenaikan tekanan darah. ${ }^{19}$ Mekanisme produksi asam urat melalui perubahan fruktosa menjadi fruktosa-1 fosfat dihati oleh enzim fruktokinase. Proses tersebut memerlukan adenosin triphosphate (ATP) yang akan dipecah menjadi adenosin diphosphate (ADP) dan Pi. Penggunaan ATP yang meningkat menyebabkan terjadinya penurunan Pi. Proses tersebut memicu aktivasi enzim adenosin monophosphate (AMP) deaminase yang berfungsi dalam regulasi produksi asam urat. Asam urat yang tinggi dapat mengakibatkan disfungsi endotel dan menurunkan bioavailabilitas NO endotel. ${ }^{21}$ Penurunan NO akan memediasi vasokonstriksi ginjal yang akan menyebabkan terjadinya salt insensitive hypertension. Selain itu asam urat dapat meningkatkan tekanan darah sistemik melalui inflamasi dan aktivasi sistem renin angiotensin (RAS). ${ }^{22}$

Asupan tinggi lemak yang disertai dengan tinggi fruktosa akan menyebabkan kenaikan berat badan. Kenaikan berat badan mengakibatkan distribusi lemak dalam tubuh meningkat. Peningkatan masa sel lemak menyebabkan peningkatan produksi angiotensinogen di jaringan lemak. Angiotensinogen berperan penting dalam peningkatan tekanan darah melalui RAS. Kadar 
RAS lokal di dalam jaringan lemak berperan dalam meningkatkan aktivitas RAS sistemik, sehingga menyebabkan kenaikan tekanan darah. ${ }^{10}$

\section{Perubahan Tekanan Darah Sistolik Sebelum Dan Sesudah Pemberian Sari Buah Belimbing Wuluh}

Hasil analisis tabel 2 menunjukan bahwa secara statistik terjadi penurunan tekanan darah sistolik yang signifikan pada kelompok kontrol negatif dan perlakuan.Sedangkan kelompok kontrol positif mengalami penurunan yang tidak signifikan. Rerata penurunan tekanan darah kelompok kontrol negatif $3,76 \%(3,29 \mathrm{mmHg})$. Walaupun secara statistik penurunan tekanan darah sistolik pada kelompok kontrol negatif signifikan tetapi secara klinis penurunan tersebut tidak signifikan karena hanya $3,29 \mathrm{mmHg}$ selama 14 hari. Hal ini dapat terjadi karena beberapa faktor salah satunya berat badan. Berat badan akan mempegaruhi aktivitas fisik sampel. Peningkatan aktivitas fisik akan mempengaruhi tekanan darah karena dapat menurunkan sitokin inflamator dan stres oksidatif. ${ }^{23}$

Penurunan tekanan darah sistolik pada kelompok perlakuan dipengaruhi oleh kandungan flavonoid, vitamin c, dan kalium yang terdapat pada sari buah belimbing wuluh. Hasil uji kandungan sari buah belimbing wuluh, per $100 \mathrm{ml}$ mengandung 41 $\mathrm{mg}$ flavonoid, 32,6 $\mathrm{mg}$ vitamin $\mathrm{C}$ dan $0,07 \%$ kalium. Kandungan vitamin $\mathrm{C}$ dalam $100 \mathrm{ml}$ sari buah belimbing wuluh setara dengan vitamin $\mathrm{C}$ yang terapat dalam 100 gram buah belimbing wuluh yaitu sebesar 32,23 mg. ${ }^{24}$ Sedangkan untuk flavonoid total belum pernah diuji secara kauntitas sehingga tidak dapat dibandingkan.

Flavonoid dan vitamin $\mathrm{C}$ merupakan antioksidan kuat untuk mengurangi stres oksidatif dan meningkatkan fungsi endotel melalui produksi NO. Vitamin C meningkatkan konsentrasi tetrahydrobiopterin intraseluler yang merupakan kofaktor sintase NO endoteliel sehingga produksi dan bioaktivitas NO meningkat. ${ }^{25}$ Flavonoid akan mempengaruhi kerja dari angiotensin converting enzym (ACE). Penghambatan ACE akan menginhibisi perubahan angiotensin I menjadi angiotensin II, yang menyebabkan vasodilatasi sehingga tahanan resistensi perifer turun dan dapat menurunkan tekanan darah. ${ }^{26,27}$

Kalium dalam plasma yang tinggi merangsang produksi dan pelepasan aldosteron dari korteks adrenal. Kalium berperan dalam memperbesar ukuran sel endotel dan meningkatkan produksi NO yang akan memicu reaksi dilatasi dan reaktivasi vaskuler yang akan menurunkan tekanan darah. ${ }^{28}$ Kalium juga berperan dalam meningkatkan ekskresi natrium dan air melalui penghambatan pelepasan renin. Terhambatnya renin akan mencegah pembentukan angiostensin I dan II sehingga akan menurunkan sensitivitas vasokonstriksi. ${ }^{29}$

\section{SIMPULAN}

Pemberian sari buah belimbing wuluh sebanyak $2 \mathrm{ml} / 200 \mathrm{gBB}$ tikus selama 14 hari dapat menurunkan tekanan darah sistolik secara signifikan.

\section{SARAN}

Perlu dilakukan inovasi produk buah belimbing wuluh dalam bentuk olahan lain untuk mengurangi rasa asam.

\section{DAFTAR PUSTAKA}

1. Appel LJ. Modern nutrition in health and disease. 11th ed. Philadelphia: Lippincott Williams and Wilkins; 2014. Chapther 66, Diet And Blood Preassure; p.875-885.

2. Mahan LK, Escott-Stump S, Raymond JL. Krause's food and the nutrition care process. 13th ed. Missouri: Elsevier Saunders, 2012.

3. Epidemiology Of Hypertension. Journal of the Association of Physicians of India (JAPI). 2013;61.

4. American Heart Association (AHA). High blood preassure-2014 statistical fact sheet. United Stated: AHA, 2014.

5. World Health Organization (WHO). A global brief on hypertension: silent killer, global public health crisis. Geneva: WHO, 2013

6. World Health Organization (WHO). Hypertension. World Health Rankings [serial online] 2011[cited 2015 April 13]. Available from: http://www.worldlifeexpectancy.com/cause-ofdeath/hypertension/by-country/.

7. Kementerian Kesehatan Repubulik Indonesia. Riset Kesehatan Dasar (RISKESDAS) 2013. Jakarta: Institusi, 2013.

8. Brown CM, Dullo AG, Yepuri G, Montani JP. Fructose ingestion acutely elevates blood pressure in healthy young humans. Am J. 2008;294(3):730-733.

9. Jena M, Jena J, Biswal Sb, Mishra S, Pal A. Effect of Eclipta alba on fructose induced hypertension in albino rats. International Journal of Pharmacy and Pharmaceutical Sciences. 2013;5(3):281-285.

10. Haris S, Tambunan T. Hipertensi pada sindrom metabolik. Sari Pediatri. 2009;11(4):257-63.

11. Lim TK. Edible medical and non-medical plants: Volume 1, Fruit. 1th Ed. New York: Springer. Chapther 8, Averrhoa bilimbi; p.448-452.

12. Bhaskar B, Shantaram M. Morphological and biochemical characteristics of Averrhoa fruits. Internl $\mathbf{J}$ Of Pharmaceutical, Chemical, And Biological Sciences (IJPCBS). 2013;3(3):924-928.

13. Oberleithner H, Callies C, Kusche-Vihrog K, Shahin V, Riethmu C, MAcGregor G, Wardener H. Potassium softness vascular endhotelium and 
increases nitic oxide release. PNAS. 2009;106(8):2829-2834.

14. Bhaskar B, Shantaram M. Morphological and biochemical characteristics of Averrhoa fruits. Internl $\mathbf{J}$ Of Pharmaceutical, Chemical, And Biological Sciences (IJPCBS). 2013;3(3):924-928.

15. Zakaria SK. Development of osmotic dehydrated fruit of Averrhoa bilimbi and zingiber officinalle roscoe and its antioxidant activities, physicochemical properties and sensory evaluation. Malaysia: Universiti Teknologi MARA, 2013.

16. Surialaga S, Dhianawaty D, Martina A, Andreanus. Efek antihiperkolesterol jus buah belimbing wuluh (Averrhoa bilimbi L) terhadap mencit galur Swiss webster hiperkolesterolemia. MKB. 2013;45(2):125-9.

17. Armenia, Megawati, Rusdi. Efek penurunan gula darah air perasan buah belimbing wuluh (Averrhoa bilimbi Linn) pada mencit diabetes yang diinduksi aloksan dan mencit yang dibebani glukosa. Jurnal Sains dan Teknologi Farmasi. 2014;9(2):63-69.

18. Jena M, Jena J, Biswal Sb, Mishra S, Pal A. Effect of Eclipta alba on fructose induced hypertension in albino rats. International Journal of Pharmacy and Pharmaceutical Sciences. 2013;5(3):281-285.

19. Kim DH, Khitan Z. Fructose: a key factor in the development of metabolic syndrome and hypertension. Journal of Nutrition and Metabolism. 2013:1-12.

20. Vasdev S, Ford CA, Longerich L, Gadag V and Wadhawan S. Role of aldehydes in fructose induced hypertension. Molecolar and Celluler Biochemistry. 1998; 181:1-9.

21. Nakagawa T, Tuttle KR, Short RA, Johnson RJ. Hypothesis: fructose-induced hyperuricemia as a causal mechanism for the epidemic of the metabolic syndrome. Nature Clin Pract Nephrol 2005;1:80-6.

22. Chaudhary K, Malhotra K, Sowers J, Aroor A. Uric acid-key ingredient in the recipe for cardiorenal metabolic syndrome. Cardiorenal medicine. 2013;3:208-220.

23. Anane EA, Agyemang C, Codjoe SNA, Ogedegbe G, Atkins AG. The association of physical activity, body mass index and the blood pressure levels among urban poor youth in Accra, Ghana. BMC Public Health. 2015;15(269):2-9.

24. Lim TK. Edible medical and non-medical plants: Volume 1, Fruit. 1th Ed. New York: Springer. Chapther 8, Averrhoa bilimbi; p.448-452.

25. Juraschek SP, Guallar E, Appel LJ, Miller ER. Effects of vitamin $\mathrm{C}$ supplementation on blood pressure: a meta-analysis of randomized controlled trials. Am J Clin Nutr. 2012;95:1079-88.

26. Balasuriya N, Rupasinghe. Plant flavonoids as angiotensin converting enzyme inhibitors in regulation of hypertension. Functional Foods in Health and Disease 2011;1(5):172-188.

27. Loizzo MR, Said A, Tundis R, Rashed K, Statti GA, Menichini F.. Inhibition of angiotensin converting enzyme (ACE) by flavonoids isolated from
Ailanthus excelsa (Roxb) (Simaroubaceae). Phytother 2007;21:32-36.

28. Oberleithner H, Callies C, Kusche-Vihrog K, Shahin V, Riethmu C, MAcGregor G, Wardener H. Potassium softness vascular endhotelium and increases nitic oxide release. 2009.

29. Houston MC. The importance of potassium in managing hypertension. Curr Hypertens Rep. 2011. doi 10.1007/s11906-011-0197-8. 